\title{
THE EFFECT OF EDMODO-BASED BLENDED LEARNING ON STUDENTS' ACHIEVEMENT
}

\author{
Jesi Jecsen Pongkendek*, Evy Nurvitasari, Ardi Firmansyah \\ Fakultas Keguruan dan Ilmu Pendidikan, Universitas Musamus, Merauke, Indonesia
}

\begin{abstract}
Blended learning is a mixed learning model that combines online and face-to-face learning that utilizes a website or application that can be accessed with a smartphone, laptop, or computer connected to the internet network. Blended learning is an alternative learning model applied during the Covid-19 pandemic. This study aims to determine the effect of the Edmodo-based blended learning model on student learning outcomes. This type of research is pre-experimental with one group pretest-posttest design. The research was conducted at SMAN 1 Kurik with Class XI MIPA 1, which consisted of 26 students as the research sample. Research data was obtained in learning outcomes data conducted at the beginning and end of learning. Student learning outcomes data were analyzed parametrically with paired sample t-test. Based on the results of the study, it was obtained that students' learning completeness was $85 \%, \mathrm{~N}$-Gain was 0.56 (medium category), and t-count was 20.79 ( $\mathrm{t}$-count $>\mathrm{t}$-table). Through this research, it can be concluded that there is an influence of the Edmodo-based blended learning model on the chemistry learning outcomes of students in class XI MIPA 1 SMAN 1 Kurik.
\end{abstract}

Keywords: Edmodo; Blended Learning; Learning outcomes

\section{INTRODUCTION}

Improving the quality of education can support efforts to realize superior human resources and have the ability to compete in the global era (Ariyatun \& Octavianelis, 2020). Competition in the current global era is supported by advances in science, technology, and information and the outbreak of the Industrial Revolution 4.0. The Industrial Revolution 4.0 has a broad impact on various aspects of life. In the industrial revolution 4.0, humans take advantage of the role of digitization to integrate various sources of information. In the industrial era 4.0, they apply the internet of things and analytical activities to physical technology, namely artificial intelligence, robotics, cognitive technology, and advanced computing (Murti, 2019). The development of technology, information, and communication in the industrial era significantly impacted various fields. One of them is the changes given in the field of education. Changes in the field of education are changes in educating and teaching. Learning models and media are needed to adjust the development of science and technology in meeting learning needs and achieving learning objectives (Fitriani, 2019). Teachers must also innovate in creating active, effective, innovative, fun, creative, meaningful, and joyful learning (Harta et al., 2020). In addition, the education system is needed to respond to changes in the era of the industrial revolution 4.0.

To respond to the industrial era 4.0, the Ministry of Education and Culture (Nasrullah et al., 2017) created a new literacy movement: literacy, numeracy literacy, scientific literacy, financial literacy, digital literacy, and cultural \& civic literacy. Digital literacy has a major impact on changes in the field of education. Digital literacy is an individual's ability to use communication tools and technology to access, analyze, manage, integrate and evaluate information, seek new knowledge and communicate effectively with others (Harjono, 2013).

\footnotetext{
${ }^{*}$ Corresponding author: Fakultas Keguruan dan Ilmu Pendidikan, Universitas Musamus, Merauke, Indonesia. Email: pongkendek@unmus.ac.id
} 
In addition, since the spread of the Corona virus pandemic in Indonesia, the government has taken various measures to suppress its spread. To suppress the spread of Corona Virus Disease (Covid-19), the Minister of Education and Culture (Surat Edaran Nomor 4 Tahun 2020 Tentang Pelaksanaan Kebijakan Pendidikan Dalam Masa Darurat Penyebaran Corona Virus Disease (COVID-19), 2020) provides instructions for carrying out the learning process from home. One alternative learning model used during the Covid-19 emergency is the blended learning model.

Blended learning is a mixed learning model that combines online and face-to-face learning that utilizes websites or applications accessed via smartphones and laptops with an internet network (Angraini et al., 2018). According to (Albiladi \& Alshareef, 2019), blended learning is a learning strategy that combines traditional or face-to-face learning with online or face-to-face learning. Blended learning is a learning model that has combined various fields such as teaching methodologies, online teaching and learning, and learning technology

Blended learning is a formal education program where students can learn through partially delivered content and online instruction. Students have control over time, place, and location and increase students' responsibility for their learning. Blended learning can make teacher-student interaction unlimited, facilitate teacher-student communication, as well as students' flexibility in accessing teaching materials (Subagiyo, 2019).

The purpose of blended learning is to combine traditional or face-to-face learning and online learning characteristics to increase independence, activeness, communication between teachers and students or students with students, and optimize the available time (Khoiroh et al., 2017). In the learning process, blended learning is connected to e-learning learning resources connected to online learning that requires media. The media used in the blended learning model is a website or application. One of them is Edmodo. Edmodo is an application that can create, manage, and communicate between teachers, students, and students through smartphones or laptops connected to the internet network. According to Ekayati (Ekayati, 2018), the blended learning model has the following learning concepts:

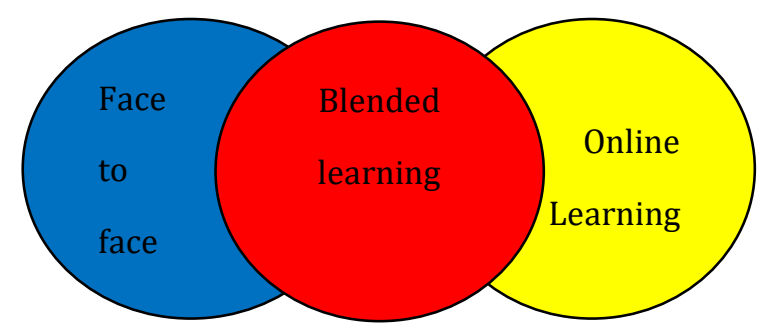

Figure 1. Blended learning model concept

According to Chaeruman (2013), there are four quadrants of blended learning settings: 1) Direct synchronous, direct synchronous is a learning condition carried out at the same time and place. Learning settings like this occur in conventional learning, where teachers and students are in the same place and, at the same time, learning in the classroom. Examples of lecture learning methods and laboratory practice. 2) Virtual synchronous is a learning condition that is carried out at the same time and in different places from each other. Examples of learning methods are presentations, discussions, tutorials, demonstrations using technology and communication tools such as video conferencing and audio conferencing. 3) Independent asynchronous, independent asynchronous is learning that can take place anywhere and anytime independently according to each student's conditions and learning speed. For example, students are facilitated with digital teaching materials known as learning objects in various formats, both media based on text, animation, audio, video, simulation, games or a combination of all of them (hypermedia). 4) Collaborative asynchronous, collaborative asynchronous learning that can take place anywhere and 
anytime through collaboration between two or more people. Examples of learning discussion methods, tutorials and questions and answers through online discussion forums.

Blended learning applied in this research is virtual synchronous and independent asynchronous. Synchronous virtual was chosen because schools were closed and learning from home. Virtual sync via the google meets app, while standalone asynchronous use the Edmodo app. The Edmodo application is a free and safe application that can be used by teachers and students in the distance and face-to-face learning process and makes it easier for teachers to provide material and communicate with students (Ekayati, 2018). Edmodo is an e-learning management platform that can be used on computers and mobile phones with easy download and installation and combines communication functions, social functions and learning functions.

Teachers and students use the Edmodo application as an interactive learning medium that makes students more active in the learning process. Edmodo can be accessed by teachers, students and parents anywhere and anytime as long as they have internet network access. A previous research study (Angraini et al., 2018) showed that by using the Edmodo-based blended learning model, students were interested in learning and interested in learning, including a a very strong category $(85.8 \%)$. The average remedial and enrichment learning outcomes using Edmodo are in the very good category (80.5). The second study (Fitriana, 2017) applied the blended learning model to the chemical separation course of chromatographic material to improve the quality of learning. In this study, the material used was a buffer solution. The results showed that students were satisfied and actively involved in the learning process using the blended learning model, and the results of $60 \%$ online meeting class learning showed that learning interactions between students were more frequent than in classes with $40 \%$ online.

Learning outcomes are abilities obtained after going through a learning process that can be measured in the form of mastery or level of knowledge, attitudes, and skills resulting from the learning process at school (Pongkendek et al., 2019). And learning outcomes are indicators in achieving student success in the learning process (Pongkendek et al., 2021). Self-learning is a process of students trying to change attitudes and behaviour caused by changes in the way they think about the reality experienced around them (Werang, 2012). In teaching and learning activities, the teacher will determine the goals and directions of learning. Later, it will be seen that students who can achieve the goals and are in line with the direction of learning are considered successful students. Learning outcomes are also a measure of student success and success in learning activities. The emergence of new behaviour as a result of integration between past and new experiences is a tangible form of the success of the learning process. Two main factors can affect student learning outcomes: internal and external factors (Surjaman, 2017). Internal factors that can impact student learning outcomes are mainly due to learning disabilities, including lack of motivation, interest, talent, and level of intelligence of students. Meanwhile, external factors that can impact learning outcomes are mainly due to learning problems, including incorrect implementation of a learning strategy, lack of interest in learning due to poor management of learning activities, and an uncomfortable environment for learning activities.

Based on the interviews with chemistry teachers and students at SMAN 1 Kurik, there are several problems faced by teachers and students, including the use of learning models that are not optimal; one of the learning models used by teachers is e-learning. In e-learning, the teacher has a problem: opening a website for learning that takes a long time, so class hours are reduced. In addition, students have difficulty accepting the teacher's explanation in delivering material because students need more time to understand the material given, and from the results of the 2019/2020 odd semester final exams, there are still $46 \%$ of students who have not reached the KKM this: 
Table 1. Student learning outcomes of class XI MIPA 1

\begin{tabular}{ll}
\hline Not pass the test & 12 \\
\hline Pass the test & 14 \\
Total student & 26
\end{tabular}

Through the explanation above, this research was carried out to find out the Effect of Blended Learning Based on Edmodo Applications on Students' Chemistry Learning Outcomes

\section{METHODS}

This experimental research used is a pre-experimental research design with one group pretest-posttest design. According to (Sugiyono, 2011) the research design pattern is described as follows:

\section{$\mathbf{O}_{1} \mathbf{X} \mathbf{O}_{2}$}

Figure 2. One Group Pretest-Postest Design

SMAN 1 Kurik became the place for conducting the research. The respondents were class XI MIPA 1 (26 students) who have smartphones. The research sample was taken employing purposeful sampling, where sampling was not based on region or strata but wanted to achieve certain goals desired by the researcher (Werang, 2015). Descriptive statistics and inferential statistics analyzed the research data. The N-Gain test formula is as follows (Husna et al., 2013) :

$$
\mathrm{N}-\text { Gain }=\frac{\text { Posttest Score }- \text { Pretest Score }}{\text { Maksimum Score }- \text { Pretest Score }}
$$

In determining the level of improvement in student learning outcomes, the following criteria can be used:

Table 2. N-Gain score category

\begin{tabular}{ll}
\hline Score & Category \\
\hline N-Gain $<0.3$ & Low \\
$0.7>$ N-Gain $\geq 0.3$ & Medium \\
N-Gain $\geq 0.7$ & High \\
\hline
\end{tabular}

Inferential data analysis with paired sample t-test was applied following prerequisite analysis (normality and homogeneity tests).

\section{RESULT AND DISCUSSION}

The research was carried out by applying the Edmodo-based blended learning model in chemistry learning. Learning is carried out in 4 meetings. Students follow learning from home using smartphones. In conducting the research, students of class XI MIPA 1 were given a pretest first to determine the initial data on student chemistry learning outcomes. After being given treatment, the researcher gave a posttest which was useful to find out the final data on chemistry learning outcomes. 


\section{Learning outcomes}

Table 3. Learning outcomes

\begin{tabular}{llll}
\hline Number & Statistics & Prestest & Posttest \\
\hline 1 & Sampel & 26 & 26 \\
2 & KKM & 71 & 71 \\
3 & Highest score & 62 & 90 \\
4 & Lowest score & 23 & 53 \\
5 & Ideal score & 100 & 100 \\
6 & Average score & 42.46 & 74.54 \\
7 & Standard deviation & 9.08 & 10.13 \\
\hline
\end{tabular}

The results of the calculation of the pretest score, the average score is 42.46 with the highest score of 62 and the lowest score of 23. This shows that students have not been able to work on the questions well because they have not studied the material in the questions. In the calculation of posttest results, the average score of student chemistry learning outcomes was 74.54 , with the lowest score of 53 and the highest score of 90; from 26 students, four students scored below the KKM. From these data, the difference between the average pretest and posttest scores is 32.08 , which indicates an increase in understanding of the material in the questions studied by students after using the blended learning model based on the Edmodo application.

\section{N-Gain test result}

After the data was obtained from the students' pretest and posttest results, the N-Gain calculation was carried out to determine the average increase in chemistry learning outcomes. This increase can be seen from the average N-Gain value, while the average N-Gain data is 0.56 . This shows an increase in the pretest and posttest scores which differ in the medium category. The results of the N-Gain calculation can be seen in Table 4 below:

Table 3. N-Gain test result

\begin{tabular}{llll}
\hline Data & Pretest & Posttest & N-Gain \\
\hline Average & 42,46 & 74,54 & 0,56 \\
\hline
\end{tabular}

\section{Hypothesis testing}

In the hypothetical test for the paired sample t-test, the normality and homogeneity of the data were tested first. The normality test results showed that the data were normally distributed, and the homogeneity test of the data showed that the pretest and posttest data were homogeneous. Therefore, the test can be continued for the paired sample t-test. This test is intended to see whether there is an effect of student chemistry learning outcomes on the subject of buffer solutions before being given treatment with the test criteria being accepted $\mathrm{H}_{0}$ if $\mathrm{t}_{\text {count }}<\mathrm{t}$ table, and reject $\mathrm{H}_{0}$ if $t_{\text {count }}>t_{\text {table }}$ with $d f=(n-1)$ and a significance level of $5 \%$. From the results of calculations using SPSS version 25, the results are shown in Table 5 below: 


\begin{tabular}{lccccc} 
Table 5. t-test result & \multicolumn{1}{l}{} & & \\
\hline Testing & $\mathrm{N}$ & $\mathrm{Dk}$ & $\mathrm{A}$ & $t_{\text {table }}$ \\
\hline Pretest & 26 & 25 & 0,05 & $-20,79$ & 2,06 \\
Posttest & 26 & & & & \\
\hline
\end{tabular}

The results of the calculations in table 5 above show that $t$ count has a negative value of 20.79. $\mathrm{t}$ count is negative because the average score of the pretest results is lower than the average posttest value, in a context like this, the $t$ count value can be positive (Istiqomah, 2019). The value of $\mathrm{t}_{\text {count }}$ becomes 20.79 , so that $\mathrm{t}_{\text {count }}>\mathrm{t}$ table, it can be concluded that reject $\mathrm{H}_{0}$ and accept $\mathrm{H}_{\mathrm{a}}$ which is accepted means that blended learning based on the Edmodo application affects the chemistry learning outcomes of students in class XI MIPA 1 SMAN 1 Kurik.

Through the results of this study, in every meeting, students should be actively involved so that they can get the opportunity to be able to build their knowledge so that they gain a deep understanding and the learning process is more varied such as uploading, downloading and watching videos and answering online quizzes. The increase in learning outcomes in the average posttest score was higher than the pretest results. This indicates an increase in chemistry learning outcomes after being treated with the application of a blended learning model based on the Edmodo application in chemistry learning. This is evidenced by the results of the calculation of NGain 0.56 in students included in the medium category, where the N-Gain value is the difference between the posttest and pretest scores which means there is an increase in students' understanding or mastery of concepts after learning using the blended learning model based on the Edmodo application.

The results of the data analysis that have been carried out show that the results of learning chemistry are better after blended learning based on the Edmodo application is implemented. This is following research from (Angraini et al., 2018) that Edmodo-based blended learning significantly affects student learning outcomes. These results are due to the blended learning model providing more opportunities for students to learn, maximizing effectiveness in learning, and increasing student independence (Basuki, 2018).

In blended learning, students can improve communication and interaction between teachers and students or other students by utilizing available media. The media used in this study is Edmodo. The media used in this research is Edmodo. Teachers and students use Edmodo as an interactive learning media that makes students play an active role in improving student learning outcomes. In addition to connecting teachers and students, Edmodo can connect with parents, so parents can easily see the development of children in the learning process (Angraini et al., 2018).

The Edmodo application helps students communicate and interact anywhere and anytime via a smartphone or laptop connected to the internet network. In addition, the Edmodo application helps students download materials, quizzes and assignments given by the teacher and is responsible for collecting assignments or quizzes online (Ekayati, 2018). Furthermore, the Edmodo application can teach students how to behave online and be responsible in managing their learning activities with a secure system (Daulay \& Manurung, 2016).

\section{CONCLUSION}

This study found an influence of the blended learning model based on the Edmodo application on the chemistry learning outcomes of students in class XI MIPA 1 SMAN 1 Kurik. This finding is indicated by the percentage of complete learning outcomes of $85 \%$, N-Gain of 0.56 (medium category), and $t_{\text {count }}$ of 20.79 ( $\mathrm{t}_{\text {count }}>\mathrm{t}_{\text {table). }}$. Through this research, teachers should apply the blended learning model in the implementation of learning because the learning model provides 
flexibility for students in learning and can help teachers during the current Covid-19 pandemic. In addition, teachers should use the Edmodo application media in chemistry learning because the media can improve interaction and communication between teachers and students, and teachers can provide materials, quizzes and assignments that can be accessed by students anywhere and anytime.

\section{REFERENCES}

Albiladi, W. S., \& Alshareef, K. K. (2019). Blended Learning in English Teaching and Learning: A Review of the Current Literature. 10(2), 232-238. https://doi.org/http://dx.doi.org/10.17507/jltr.1002.03

Angraini, M. R., Muharini, R., \& Lestari, I. (2018). Penerapan Blended Learning Berbasis Edmodo Terbadap Minat Dan Hasil Belajar Siswa SMAN 9 Pontianak. 1-12.

Ariyatun, A., \& Octavianelis, D. F. (2020). Pengaruh Model Problem Based Learning Terintegrasi Stem Terhadap Kemampuan Berpikir Kritis Siswa. JEC: Journal of Educational Chemistry, 2(1), 33. https://doi.org/10.21580/jec.2020.2.1.5434

Basuki, A. R. R. ismet. (2018). Pengaruh Model Pembelajaran Blended Learning Didukung E-Learning ( Edmodo, Schoology ) Dan Motivasi Berprestasi Terhadap Kompetensi Siswa Pada Mata Pelajaran Instalasi Motor Listrik. Di SMK PGRI 1 Surabaya. 3, 193-200.

Chaeruman, U. A. (2013). Merancang Model Blended Learning. 399-409.

Daulay, U. A., \& Manurung, B. (2016). Pengarub Blended Learning Berbasis Edmodo dan Motivasi Belajar Terbadap Hasil Belajar IP A Biologi dan Retensi Siswa pada Sistem Peredaran Darah Manusia di Kelas VIII SMP Negeri 5 Medan. 6(1), 260-266.

Ekayati, R. (2018). Implementasi Metode Blended Learning Berbasis. 4(2), 50-56.

Fitriana, N. (2017). Mata Kuliah Pemisahan Kimia Materi Kromatografi Untuk Meningkatkan Kualitas Belajar. 4, 46-54.

Fitriani, R. S. (2019). Model Pembelajaran Berbasis Saintifik Menggunakan Alat Peraga E Pen Interaktif dengan Muatan Kearifan Lokal pada Era Industri 4 . 0 untuk Pengajaran BIP A di Uninus. 6(2), 4046. https://doi.org/10.33603/dj.v6i2.2187

Harjono, H. S. (2013). Literasi Digital: Prospek dan Implikasinya dalam Pembelajaran Bahasa. 53(9), 1689-1699. https://doi.org/10.1017/CBO9781107415324.004

Harta, J., Limbong, S. A., \& Waruwu, E. E. (2020). Pengembangan Media Pembelajaran Asam Basa Inovatif Berbasis Green Labyrinth untuk SMA. J-PEK (Jurnal Pembelajaran Kimia), 5(1), 17-31. https://doi.org/10.17977/um026v5i12020p017

Husna, Ikhsan, M., \& Fatimah, S. (2013). Peningkatan Kemampuan Pemecahan Masalab Dan Komunikasi Matematis Siswa Sekolah Menengah Pertama Melalui Model Pembelajaran Kooperatif Tipe Think-Pair-Share (Tps). 1(2), 81-92.

Istiqomah. (2019). Pembelajaran Menulis Karangan Deskripsi Dengan Model Kooperatif Tipe STAD Terhadap Siswa Kelas X Man 3 Aceb Utara. 19(2), 216-235.

Khoiroh, N., Munot, \& Lilik, A. (2017). Pengarub Model Pembelajaran Blended Learning Dan Motivasi Belajar Terhadap Hasil Belajar Siswa. 10, 97-110.

Lazem, S. (2019). On Designing Blended Learning Environments for Resource-Challenged Communities. 14(12), 183-193. https://doi.org/https://doi.org/10.3991/ijet.v14i12.10320 Shaimaa

Surat Edaran Nomor 4 Tahun 2020 Tentang Pelaksanaan Kebijakan Pendidikan Dalam Masa Darurat Penyebaran Corona Virus Disease(COVID-19), (2020). 
Murti, H. W. (2019). Kajian Industri 4.0 Untuk Penerapannya Di Indonesia. Jurnal Manajemen Industri Dan Logistik, 01, 1-13. https://doi.org/10.30988/jmil.v3i1.59

Nasrullah, R., Aditya, W., Satya, T. I., Nento, M. N., Hanif, N., Miftahussururi, \& Akbari, Q. S. (2017). Literasi Digital. Kementerian Pendidikan dan Kebudayaan.

Pongkendek, J. J., Parlindungan, J. Y., \& Marpaung, D. N. (2019). Effectiveness of the Application of Team Games Tournament Cooperative Learning Model (TGT) to Improve Learning Outcomes of Students of Class XI Science 1 SMA Frater Makassar in the Principal Material of Salt Hydrolysis. IOP Conference Series: Earth and Environmental Science, 343(1). https://doi.org/10.1088/1755-1315/343/1/012228

Pongkendek, Jesi Jecsen, Marpaung, D. N., Nurvitasari, E., \& Parlindungan, J. Y. (2021). The Use Of Chemsketch to Increase Student Learning Outcomes and Motivation in Learning Hydrocarbons. J-PEK (Jurnal Pembelajaran Kimia), 6(1), 9-18. https://doi.org/http://dx.doi.org/10.17977/um026v6i12021p009

Subagiyo, S. (2019). Penerapan Model Blended Learning untuk meningkatkan Pemahaman Konsep Termokimia Siswa. Journal of Educational Chemistry (JEC), 1(1), 1. https://doi.org/10.21580/jec.2019.1.1.3830

Sugiyono. (2011). Metode Penelitian Kuantitatif, Kualitatif dan R\&D. Alfabeta.

Surjaman, T. (2017). Penilaian Hasil Proses Belajar Mengajar. Remaja Rosdakarya.

Werang, B. R. (2012). Belajar dan Pembelajaran. Elang Mas.

Werang, B. R. (2015). Pendekatan Kuantitatif dalam penelitian sosial. Calpulis. 